\title{
IMPACT OF DIFFERENT CHEMICALS ON THE POST HARVEST QUALITY OF PEAR (Pyrus Spp L.) FRUIT: A REVIEW
}

\author{
Kunal Sharma \\ Department of Horticulture \\ Lovely Professional University, Phagwara, Punjab, India
}

\begin{abstract}
Pear (Pyrus Spp L.) is one of the most harvested temperate fruit crop right after Apple. Pear belongs to the family Rosaceae along with some best known temperate tree fruits. Pear being one of the popular temperate fruit but is having a short storable life under room temperature conditions. The capability of being able to manage keeping quality of the stored fruit is must during the post harvest storage of the crops along with being able to increase the storable life of those fruits. Various post harvest technology are being used to sustain the fruit's keeping quality and also to increase those fruits storable time period. Being a crop prone to decay, diseases such as fungal diseases (mould) and short shelf life different researcher has recommended the use of different chemicals to preserve the quality as well as increase the storage lifetime of the fruits. Chemical such as Calcium have been proven to be effective in this post harvest management of fruits by having effects on the physiochemical fruits.
\end{abstract}

Keywords: Postharvest, Quality of fruits, Chemicals, storage life, Calcium, 1-MCP.

\section{INTRODUCTION}

Pear (Pyrus Spp L.) is one of the popular temperate fruit crop behind apple. It has a high productivity, high nutritive value and good range of adaptability under different agro climatic areas. Common Pear (Pyrus communis) is said to be originated from the temperate region of the Europe and Western Asia. Pear is diploid with chromosome no. $2 \mathrm{n}=$ $2 x=34$ and belong the family of Rosaceae and sub family being Amygdaloideae and Genus is Pyrus. Pyrus communis is a cultivated form and is derived generally from P.caucasia Fed. and P. fivalis Jaq. Pear is deciduous, rarely evergreen trees or shrubs. All species are self sterile, cross fertile and sexually diploids $(2 n=34)$ in nature. The different species are graft compatible in nature. The fruits are of pyriform pome in shape and flesh of pear fruit contains the stone cell. Pear is rich in foliate vitamin C, copper and potassium. They are also a good source of polyphenol antioxidant.
Pear being a popular crop across the world with China being the largest producer of Pear followed by countries like Argentina, Italy, USA. India currently stands in at 8th position in production. The total estimated production in world was of about 24,168,309 metric tons with contributing with approximately $16,410,000$ metric tons which being about two third of the total production and 67\% of total world production and India contributing with about 346,000 tones (FAO, 2017). In India Pear is cultivated in the Jammu \&Kashmir, Himachal Pradesh, Uttarakhand and Punjab, Haryana, Uttar Pradesh cultivating the low chilling Pears. Jammu and Kashmir is the leading state in the production of Pear being 94.42 in 000 tones with a share of $29.23 \%$ of total production of 322.99 in 000 tones of that year. (NHB, 2015-16).

The objective of this review is to determine that whether the chemical can be used for the purpose of retaining the Qualities of the Pear fruit while also having a desirable

*Corresponding author: Kunal.31.5.1998@gmail.com 
impact on the storage time of the Pear fruits. This can be determine if the chemicals have good effect on the physiochemical parameters such as Fruit firmness, TSS, Core-Browning, respiration rate and other parameters.

\section{IMPORTANCE OF CHEMICALS ON THE POST HARVEST QUALITY OF THE PEAR FRUIT}

During the Post harvest of the fruits different Post harvest technologies are used for the of maintaining the quality of the fruit and use of chemical treatment is one of those technology which is advised by many researcher for the increasing the storable time period of the produces and to sustain the keeping quality of the produce.

\section{a) Impact of Calcium in the Post harvest Quality and Physiochemical Parameters}

Calcium is considered to be an essential plant nutrient which is closely linked to quality and firmness of fruits (Sams, 1999). Calcium being an important nutrient required by the cells for different role in structural area of cell wall and membranes. Its need by the cell is to act as a counter-cation for the organic and inorganic anions of cell's vacuole while also acting as a messenger within the cell in the cytosol (Marschner, 2011). Application of Calcium in the pre harvest or post harvest phase is said to be able in prevention of the physiological order and also increase the disease resistance ability of the harvest also said to be helpful in delaying of the ripening period of the fruit and along with it also helps in enhancing the quality of the fruits. (Manganaris et al., 2007).

The fruits were able to maximum value of mean Fruit firmness $\left(5.78 \mathrm{~kg} / \mathrm{cm}^{2}\right)$ while maintaining lower mean values of TSS to acid ratio (37.37), PME activity (2.01), Polygalacturonase (PG) (14.75) and also lowest loss in the Physiological weight of the Fruit (5.98\%) when treated with $4 \%$ of $\mathrm{CaCl}_{2}$ as compared to other treatment. The treatment of freshly harvested fruits treated with the $4 \%$ of $\mathrm{CaCl}_{2}$ for a time period of 20 and 30 minutes were effective along with treatment of $3 \%$ of $\mathrm{CaCl}_{2}$ in ambient conditions of storage. (Kumar et al., 2017)

The fruits of Asian pear cv. Pathernakh were treated with $\mathrm{CaCl}_{2}$ at different concentration and were kept for a period of 75 days under a temperature of $0-1^{\circ} \mathrm{C}$ and relative humidity of 90-95\%. The Mean Fruit firmness (15.82 lb) of Asian Pear was lowest in stored fruits which were dipped in the solution of $\mathrm{CaCl}_{2}$ of $4 \%$ concentration. The core browning was not noticed in the $\mathrm{CaCl}_{2} @ 2 \%$ and @4\% up to $45^{\text {th }}$ day of storage period and even with succession in the storage period browning was observed in just $5 \%$ of the total fruits after $60^{\text {th }}$ and $75^{\text {th }}$ day of storage in fruit treated with $\mathrm{CaCl}_{2} @$ 2\%and @4\% respectively. The fruits dipped in solution of $\mathrm{CaCl}_{2} @ 4 \%$ concentration had maximum TSS $\left(14^{\circ} \mathrm{B}\right)$ and total sugar $(8.30 \%)$. The fruits which were treated with $4 \%$ of $\mathrm{CaCl}_{2}$ had a favorable and desired impact on the physiochemical parameters during storage as compared to those untreated fruits. (Mahajan et al., 2004)

The fruits were experimented were kept in a temperature of $-1^{\circ} \mathrm{C}$ for period of 12 weeks. The slices that were stored in Controlled atmosphere of $0.5 \%$ of $\mathrm{O}_{2}$ of the dipping of $1 \%$ $\%$ of $\mathrm{CaCl}_{2}$ were very effective in keeping the firmness and a lighter colour of those slices. On the $8^{\text {th }}$ day of the storage in treatment of $1 \%$ of $\mathrm{CaCl}_{2}$ at a controlled atmosphere of $0.5 \% \mathrm{O}_{2}$ had much firmed slices as compared to $1 \%$ of $\mathrm{CaCl}_{2}$ at air. A $1 \%$ of $\mathrm{CaCl}_{2}$ dip proved to be effective to reduce the browning and also in reducing the loss of firmness of the sliced fruits. The combination of $0.5 \% \mathrm{O}_{2}$ and $1 \%$ of $\mathrm{CaCl}_{2}$ was more effective in nature and was able to control the browning and maintain the fruit firmness of the sliced fruits compared to that the treatment which was introduced to the air. (Rosen et al., 1989)

The various treatments of $\mathrm{CaNO}_{3}$ and $\mathrm{GA}_{3}$ were effective in the process of minimizing the Physiological Loss of weight, in maintaining the Firmness of the fruits, TSS, titratable acidity, total sugar content and other parameters. After the end of the storage period the most effective treatment was noted to be in the fruits which were treated with $\mathrm{CaNO}_{3}$ treatment of $3 \%$ with lowest PLW of $4.81 \%$, and highest in fruit firmness(3.88 kgf), sensory quality(7.15), TSS(12.35\%), total sugar(8.45\%). In case of $\mathrm{GA}_{3}$ the minimum PLW (5.59\%) was noticed in the treatment with $60 \mathrm{ppm}$ concentration and maximum values of fruit firmness were noticed in those fruit which were treated with GA $@$ @ 40, 60 ppm of 3.55 kgf in both cases. In case of TSS (12.31\%) and Total sugar (8.38\%) were highest noticed in treatment of $\mathrm{GA}_{3} @ 60$ ppm. Both $\mathrm{CaNO}_{3}$ and $\mathrm{GA}_{3}$ were both effective in reducing the PLW, maintaining the fruit firmness, TSS, Total Sugar content and other parameters with most effective being the $3 \%$ of $\mathrm{CaNO}_{3}$ and in case of $\mathrm{GA}_{3}$ the treatment of $\mathrm{GA}_{3} @ 60$ ppm (Kaur et al., 2017). 
Table 1: Effect of Calcium Treatment on different Fruit Crops.

\begin{tabular}{|c|c|c|c|c|}
\hline S No. & Crop & $\begin{array}{l}\text { Treatment used } \\
\text { of Calcium }\end{array}$ & Effect of Calcium treatment & Source \\
\hline 01 & Apple & $4 \%$ of $\mathrm{CaCl} 2$ & $\begin{array}{l}\text { Decrease in the weight loss, pH, TSS/acidity } \\
\text { and increased the fruit firmness of fruits }\end{array}$ & Shirzadeh et al., 2011 \\
\hline 02 & Peach & $6 \%$ of $\mathrm{CaCl} 2$ & $\begin{array}{l}\text { Retarded the spoilage, sustained the fruit } \\
\text { firmness, acidity and vitamin A content }\end{array}$ & Gupta et al., 2011 \\
\hline 03 & Papaya & $2.5 \%$ of $\mathrm{CaCl} 2$ & $\begin{array}{l}\text { Increased the storage life, control on the } \\
\text { disease incidence and retarded the timing } \\
\text { of ripening process }\end{array}$ & Mahmud et al., 2008 \\
\hline 04 & Apricot & $1 \%$ of $\mathrm{CaCl} 2$ & Increased the storability period of fruits. & Antunes et al., 2003 \\
\hline 05 & Orange & $\begin{array}{l}2 \%, 4 \%, 6 \% \text { of } \\
\mathrm{CaCl} 2\end{array}$ & Reduce the incidence of rot & El Gali, 2014 \\
\hline 06 & Loquat & $\begin{array}{l}2 \% \text { and } 3 \% \\
\mathrm{CaCl} 2\end{array}$ & $\begin{array}{l}\text { Were able to sustain the highest fruit firmness, } \\
\text { TSS, ascorbic acid content reduced browning } \\
\text { index and weight loss }\end{array}$ & Akhtar, 2010 \\
\hline
\end{tabular}

\section{a) Impact of Aminoethoxyvinylglycine (AVG) and/or Oxalic acid on the Pear fruit's Quality}

The treatment of AVG and/or oxalic acid were proven efficacious in decreasing the production of ethylene and the result of which was delay in the ripening of the fruits and also was able to reduced the fruit decay. Also, AVG+ oxalic acid was very successful in reducing the respiration rate, displayed a little bit of browning while the treated fruits also produced a lower amount of sugar. The loss in the weight percentage did effectively lowered in AVG treated fruit only and also it was very impactful in maintaining the firmness of fruits and by the finishing of the storage time period AVG treatment was able to preserve a higher green colour of the fruits. Additionally, fruits treated which were treated using oxalic acid single handedly retarded the decay as well as the total loss percentage following the end of cold storage conditions and also during the short period of the marketing period (Tarabih, 2014)

The fruit's ripening of 'Abbe Fetel' fruits which were treated in the pre harvest was retarded by 5 to 15 days on the basis of the harvesting dates. After the $7^{\text {th }}$ and $14^{\text {th }}$ of the cold storage period, fruits which were treated with AVG treatment retained their unripe features partially as compared to those untreated fruits. The process of flesh softening was declined due to the post harvest application of dip treatment of AVG on the fruits. (Anderotti et al., 2004)

b) Impact of Application of 1-Methylcyclopropene (1MCP) on the storage life of the Pear fruit

The compound 1-MCP is said to being able to prevent the illeffects of ethylene in vast range of fruits. Fruits which were treated with 1-MCP showed lesser levels of Hydrogen peroxide Ascorbate content while also showing lowered ionic leakage in the storing period of fruits. The fruits which were treated with 1-MCP also showcased higher enzymatic antioxidant potential. The desirable impacts of 1-MCP on the ripening process were just not limited because of its influence on the ethylene but it was due to rise in the potential in the Pears fruits. (Larrigaudiere et al., 2004)

The fruits which were exposed to the $2 \mu \mathrm{L} \mathrm{L}^{-1} 1$-MCP while also were kept in cold conditions storage did increased the storage period with one another months as compared to fruits which were just kept under the cold storage conditions. The total sugar content of theses fruits was steady during the storage period in each and every treatment .The application of 1-MCP on the fruits and keeping them in the cold storage showcased inhibition of the sucrose loss and also in the amassing of the hexoses. The reason this was the inhibition of amassing of PpAIVI transcript and the reduction in PpSPSI transcript which resulted in the retardation of sucrose losses. Cold+1-MCP treatment can be proven to be beneficial to the market as it inhibit the sugar losses and maintaining the fruit firmness and appearance in the Japanese pear. (Itai et al., 2007)

The fruits which were treated with the 1-MCP@300 ppb had impact on the flesh firmness, texture and peel green colour had higher values and apart from that respiratory rate and ethylene production of fruits showcased lower values. Fruits treated with NO and SNP were not able to decline the fruit's rate of respiration and also the production rate of the ethylene. NO @ 20 ppm treatment of fruits was able to maintain their fruit firmness and textural features after leaving the chambers. The fruits which were treated 
with SNP@1mM and NO@20 ppm were able to maintain their peel green color when they were compared to control fruits without having any effect on the yellowing of the treated fruits during the storage. The application of treatment of 1-MCP @ 300 ppb inhibited the buttery texture and yellowing in the fruits even during exposure to environmental conditions was done. (Hendeges et al., 2016)
The fruits which were treated with a treatment of 1-MCP@ $0.2 \mu \mathrm{l}^{-1}$ the rate of softening lowered after 7days of storage at a temperature of $20^{\circ} \mathrm{C}$. The firmness of these fruits was considered acceptable for consuming even after storage time period of 14 days at the temperature of $20^{\circ} \mathrm{C}$. 1 -MCP (a) $0.2 \mu \mathrm{l} \mathrm{l}^{-1}$ when combine with cooling techniques can delay the ripening process as well can sustain an acceptable keeping quality of Pear fruits throughout the span of the storage. (Calvo et al., 2004).

Table 2: Impact of 1-MCP treatments on the different fruit's Postharvest.

\begin{tabular}{|l|l|l|l|}
\hline S No. & Crop & Effect of 1-Methylcyclopropane on the fruit crops & Source \\
\hline 01 & Orange & Inhibitory effect on the process of Degreening & Porat et al., 1999 \\
\hline 02 & Guava & Lowered the rate of respiration and also retaining the quality & Bassetto et al., 2005 \\
\hline 04 & Loquat & $\begin{array}{l}\text { Lowered Lipoxygenase, PPO activities while also retarding the } \\
\text { browning resulted in quality sustaining and prolonged shelf life }\end{array}$ & Cai et al., 2005 \\
\hline 05 & Mango & $\begin{array}{l}\text { When fruits treated with 1-MCP the fruits show delay in the } \\
\text { softening process. The treatment increased storage life while } \\
\text { maintaining the quality of the Fruit }\end{array}$ & Ahmad et al., 2013 \\
$\begin{array}{l}\text { Suppressed Anthracnose of Mango fruit in post harvest by } \\
\text { having inhibiting impact on the spore germination and mycelial } \\
\text { growth of C. gloeosporioides }\end{array}$ & Xu et al., 2016 \\
\hline
\end{tabular}

\section{a) Impact of Ascorbic acid and /or Calcium lactate and/or Cysteine on the Quality of Pear}

The low concentration of $\mathrm{O}_{2}(0.25$ or $0.5 \mathrm{kPa})$, elevated amount of the $\mathrm{CO}_{2}$ (air rich with 20,10 or $5 \mathrm{kPa}$ of $\mathrm{CO}_{2}$ ) or the superatmospheric $\mathrm{O}_{2}$ (40,60 or $80 \mathrm{kPa}$ concentration) controlled atmosphere single handedly did not efficaciously prohibited surface browning caused due to softening of these fresh cut pear slices. After cutting, the dip treatment of the $2 \%(\mathrm{w} / \mathrm{v})$ ascorbic acid, $1 \%(\mathrm{w} / \mathrm{v})$ calcium lactate and $0.5 \%(\mathrm{w} / \mathrm{v})$ cysteine with a $\mathrm{pH}$ of 7.0 notably extended the storage life of Bartlett, by preventing the loss of firmness of flesh from the slices as well also inhibiting browning on the cut surface. There was no differentiation observed in the quality evaluation of the cut slices treated with chemical preservatives and stored over night at $0^{\circ} \mathrm{C}$ and the slices which were freshly cut. The $82 \%$ of total participant judged the treated slices after the interval of stored in air at $0^{\circ} \mathrm{Cto}$ be acceptable appearance wise after 10 days of interval of storage period whereas $70 \%$ from total participants determined the flavor to be acceptable of those treated slices. (Grony et al., 2001)

The fruits which were applied with a treatment of 0.1, 1.0 and $10 \mathrm{mM}$ of Ascorbic Acid showed a reduction in Core Browning Index of $10.4 \%, 24.5 \%$ and $40.0 \%$ respectively after $180^{\text {th }}$ day of storage. The highest TSS and firmness of the fruit which were treated with AsA @ 10 mM in comparison to that of controlled fruits. AsA treatment of fruits had retarding impact on the amassing of the malondialdehyde and Hydrogen Peroxide. Furthermore, the Ascorbic Acid treatment significantly postponed the retardation of Ascorbic Acids and glutathione levels while also it preserved activates of superperoxide dismutase catalase and Ascorbate Peroxide. (Lin et al., 2007).

The application of a combination that of Chitos an coating and Ascorbic acid can prolong the time period of the weight loss and sustain a higher fruit firmness, TSS as compare to that of untreated ones. There was also decrease in the respiration rate as well as the membrane permeability while also restricting the Core browning of fruits in an effective manner eve after 60 days of storage time period. This combined treatment was also able to sustain and higher amount of Ascorbic acid content and also maintaining a higher level of antioxidative enzymes activities. (Lin et al., 2008)

b) Impact of other chemicals (Hydrogen Sulfide, Nitric Oxide, GRAS chemical, Sodium Chlorite) on the keeping life of Pear

Hydrogen sulfide gas released by Sodium Hydrosulfide was able to increase the shelf life period of the fresh sliced 
Pear. Additionally $\mathrm{H}_{2} \mathrm{~S}$ retained the higher reducing sugar levels as well as also the soluble proteins in those freshly cut Pear slices. The amassing of the hydrogen Peroxide, superoxide radicals also Malondualdehyde was retarded with the introduction of $\mathrm{H}_{2} \mathrm{~S}$ gas. Moreover $\mathrm{H}_{2} \mathrm{~S}$ was able to up-regulate the activity process of the antioxidant enzymes such as ascorbate peroxidase, guaiacol peroxidase and also catalase. $\mathrm{H}_{2} \mathrm{~S}$ was able to down regulate the activities of lipoxygenase, phenylalanine, and polyphenol oxidase as well as ammonia lyase. In addition to this the fumigation process of $\mathrm{H}_{2} \mathrm{~S}$ was able to efficaciously restricted the growth of 2 different types of the fungal microbe of the Pear fruits, Asperigillus niger, Penicllium expansum. The meaning of this was that $\mathrm{H}_{2} \mathrm{~S}$ can work as an efficacious fungicide during the Post harvest storage process. (Hu et al., 2014).

Fruits which were treated with the treatment of NO@10 $\mathrm{nl}$ $\mathrm{l}^{-1}$ for a period of 2 hours the stage of ethylene climacteric was postponed to 4 days period of time while reducing the maximum production of the ethylene by $28 \%$ and the delay in the fruit's firmness as well change of colour by 2 days time. When the same fruits were treated with another NO @ $10 \mu \mathrm{l} \mathrm{I}^{-1}$ after a period of 4 days there was even more reduction in the production of the fruits was noticed by 48\%. While the fruits which were treated with different concentration of NO@10 $\mathrm{\mu l} \mathrm{l}^{-1}$ and $50 \mu \mathrm{ll}^{-1}$ for the period of 12 hours postponed the yellowing of fruits by a time period of 2days but the rate softening rate of fruits was very much unaltered. (Sozzi et al., 2003).

The application of GARS such as Boric Acid, Sodium bicarbonate and Sodium benzoate chemical's as external treatment had a positive effect in the fruits as they retarded the TSS/acid ratio, SOD enzyme activity and decreased the $\mathrm{pH}$ while lowering the Reducing sugar and non reducing sugar's values as compared to that of untreated fruits. The concentration of Boric acid @ 3\% treatment was proved to be much more effective than other treatments of GRAS chemical in increasing the Storage time period while also keeping the quality of fruits acceptable in the low temperature condition storage. (Kaur et al., 2019).

Sodium chlorite showed a vital prohibition in the browning of sliced fruits and also inhibited the PPO activity of the slices of Pears. Sodium chlorite treatment also was efficacious in deactivation of the Escherichia coli 0157:H7 slices of Pear fruits. The combination of carboxymethyl chitosan coating and sodium chlorite on the sliced pears had a noticeable inhibitory impact on the browning reaction as well as was able to prevent the PPO activity. Furthermore the combination of Sodium chlorite with coating of either Chitosan or Carboxylmethyl chitosan was able to sustain the tissues firmness. (Xiao et al., 2011)

\section{CONCLUSION}

Application of different chemical such as Calcium based solution, Ascorbic acid, Gibberellic acid, Oxalic acid, 1MCP and Aminoethoxyvinylglycine etc. has a positive effect on the Pear fruits as Post harvest treatment. The Calcium based solutions were able to maintain the desirable quality of the produce of fruit tree by having positive impact on the physiochemical parameters of the fruits at different concentration. Gibberllic acid, Oxalic acid and Ascorbic acid can also play an important role as post harvest treatment for the storage of the fruits. Aminoethoxyvinylglycine and oxalic acid treatment were effective in delaying the respiration rate and also the ripening of the fruits. The combination of both $\mathrm{AVG}^{+}$ Oxalic acid were deemed to be effective in the retarding the respiration rate and small to less browning and also synthesis of lower sugar in fruits.1-Methylcylopropene was able to inhibited the sucrose loss while extending the storage period in fruits also preventing the amassing of the hexoses. The chemical treatments for post harvest can be applied for the purpose of extending the shelf life while also preserving the quality of the fruits at an acceptable level.

\section{REFERENCES}

1. Ahmad, A., Mohd Ali, Z., \& Zainal, Z. (2013). Delayed softening of papaya (Carica papaya L. cv. Sekaki) fruit by 1-methylcyclopropene (1-MCP) during ripening at ambient and low temperature storage conditions. Australian Journal of Crop Science, 7(6): 750-757.

2. Akhtar, A., Abbasi, N. A., \& Hussain, A. (2010). Effect of calcium chloride treatments on quality characteristics of loquat fruit during storage. Pak. J. Bot, 42(1): 181-188.

3. Andreotti, C., Bregoli, A. M., \& Costa, G. (2004). Pre-and post-harvest aminoethoxyvinylglycine (AVG) application affects maturity and storage of pear fruit. European Journal of Horticultural Science, 69(4): 147-152.

4. Antunes, M. D. C., Correia, M. P., Miguel, M. G., Martins, M. A., \& Neves, M. A. (2003, July). The effect of calcium chloride postharvest application on fruit storage ability and quality of'Beliana' and' Lindo'apricot (Prunus armeniaca L.) cultivars. In International Conference on Quality in Chains. An Integrated View on Fruit and Vegetable Quality 604 (pp. 721-726). 
5. Bassetto, E., Jacomino, A. P., Pinheiro, A. L., \& Kluge, R. A. (2005). Delay of ripening of 'Pedro Sato'guava with 1-methylcyclopropene. Postharvest Biology and Technology, 35(3): 303-308.

6. Cai, C., Chen, K., Xu, W., Zhang, W., Li, X., \& Ferguson, I. (2006). Effect of 1-MCP on postharvest quality of loquat fruit. Postharvest Biology and Technology, 40(2): 155-162.

7. Calvo, G., \& Sozzi, G. O. (2004). Improvement of postharvest storage quality of 'Red Clapp's' pears by treatment with 1-methylcyclopropene at low temperature. The Journal of Horticultural Science and Biotechnology, 79(6): 930-934.

8. El-Gali, Z. I. (2014). Control of Penicillium digitatum on orange fruits with calcium chloride dipping. $J$. Microbiol. Res. Rev, 2(6): 54-61

9. FAOSTAT. ( 2017 ). W w w. Fa o. O rg. http://www.fao.org/faostat/en/

10. Gorny, J. R., Hess-Pierce, B., Cifuentes, R. A., \& Kader, A. A. (2002). Quality changes in fresh-cut pear slices as affected by controlled atmospheres and chemical preservatives. Postharvest biology and Technology, 24(3): 271-278.

11. Gupta, N., Jawandha, S. K., \& Gill, P. S. (2011). Effect of calcium on cold storage and post-storage quality of peach. Journal of food science and technology, 48(2): 225-229.

12. Hendges, M. V., Steffens, C. A., AMARANTE, C. V. T., Neuwald, D. A., \& Brackmann, A. (2016). 'PACKHAM'S TRIUMPH'PEAR RESPONSE TO 1METHYLCYCLOPROPENE AND NITRIC OXIDE TREATMENTS. Revista Caatinga, 29(2): 283-289.

13. Hu, K. D., Wang, Q., Hu, L. Y., Gao, S. P., Wu, J., Li, Y. H., \& Zhang, H. (2014). Hydrogen sulfide prolongs postharvest storage of fresh-cut pears (Pyrus pyrifolia) by alleviation of oxidative damage and inhibition of fungal growth. PloS one, 9(1), e85524.

14. Itai, A., \& Tanahashi, T. (2008). Inhibition of sucrose loss during cold storage in Japanese pear (Pyrus pyrifolia Nakai) by 1-MCP. Postharvest biology and technology, 48(3): 355-363.

15. Kaur, A., Gill, P. P. S., \& Singh, A. (2019). Effect of GRAS chemicals on quality of pear fruits under low temperature storage. Journal of Pharmacognosy and Phytochemistry, SP1: 526-531

16. Kaur, K., Gill, P. P. S., \& Jawandha, S. K. (2017). Effect of calcium nitrate and gibberellic acid on storage life of pear (Pyrus pyrifolia) cv. nijisseiki. Applied Biological Research, 19(2): 205-208.

17. Kumar, S., \& Thakur, K. S. (2017). Influence of postharvest calcium chloride treatments on physicochemical and sensory attributes of pear cv.'Bartlett'under ambient storage conditions. Applied Biological Research, 19(3): 270-279.

18. Larrigaudière, C., Vilaplana, R., Soria, Y., \& Recasens, I. (2004). Oxidative behaviour of Blanquilla pears treated with 1-methylcyclopropene during cold storage. Journal of the Science of Food and Agriculture, 84(14): 1871-1877.

19. Lin, L., Li, Q. P., Wang, B. G., Cao, J. K., \& Jiang, W. B. (2007). Inhibition of core browning in 'Yali'pear fruit by post-harvest treatment with ascorbic acid. The Journal of Horticultural Science and Biotechnology, 82(3): 397-402.

20. Lin, L., Wang, B., Wang, M., Cao, J., Zhang, J., Wu, Y., \& Jiang, W. (2008). Effects of a chitosan-based coating with ascorbic acid on post-harvest quality and core browning of 'Yali'pears (Pyrus bertschneideri Rehd.). Journal of the Science of Food and Agriculture, 88(5): 877-884.

21. Mahajan, B. V. C., \& Dhatt, A. S. (2004). Studies on postharvest calcium chloride application on storage behaviour and quality of Asian pear during cold storage. Journal of Food, Agriculture and Environment, 2(3-4): 157-159.

22. Mahmud, T. M. M., Al Eryani-Raqeeb, A., Omar, S. S., Zaki, A. M., \& Abdul-Rahman, A. E. (2008). Effects of different concentrations and applications of calcium on storage life and physicochemical characteristics of papaya (Carica Papaya L.). American Journal of Agricultural and Biological Science. 3(3): 526-533

23. Manganaris, G. A., Vasilakakis, M., Diamantidis, G., \& Mignani, I. J. F. C. (2007). The effect of postharvest calcium application on tissue calcium concentration, quality attributes, incidence of flesh browning and cell wall physicochemical aspects of peach fruits. Food chemistry, 100(4): 1385-1392.

24. Marschner, H. (2011). Marschner's mineral nutrition of higher plants. Academic press.

25. NHB 2015-16. Statistical Database of the National Horticulture Board, Gurgaon. http://nhb.gov.in/ area_production.html.

26. Porat, R., Weiss, B., Cohen, L., Daus, A., Goren, R., \& Droby, S. (1999). Effects of ethylene and 1- 
methylcyclopropene on the postharvest qualities of 'Shamouti'oranges. Postharvest Biology and Technology, 15(2): 155-163.

27. Rosen, J. C., \& Kader, A. A. (1989). Postharvest physiology and quality maintenance of sliced pear and strawberry fruits. Journal of Food Science, 54(3): 656-659.

28. Sams, C. E. (1999). Preharvest factors affecting postharvest texture. Postharvest Biology and Technology, 15(3): 249-254.

29. Shirzadeh, E., Rabiei, V., \& Sharafi, Y. (2011). Effect of calcium chloride $(\mathrm{CaCl} 2)$ on postharvest quality of apple fruits. African Journal of Agricultural Research, 6(22): 5139-5143.

30. Sozzi, G. O., Trinchero, G. D., \& Fraschina, A. A. (2003). Delayed ripening of 'Bartlett'pears treated with nitric oxide. The Journal of Horticultural Science and Biotechnology, 78(6): 899-903.

31. Tarabih, M.E. (2014). Improving Storability of Le Conte Pear Fruit Using Aminoethoxyvinylglycine (AVG) and Oxalic acid (OA) under Cold storage Conditions. Asian Journal of Crop Science, 6(4): 320333.

32. Xiao, Z., Luo, Y., Luo, Y., \& Wang, Q. (2011). Combined effects of sodium chlorite dip treatment and chitosan coatings on the quality of fresh-cut d'Anjou pears. Postharvest Biology and Technology, 62(3): 319-326.

33. Xu, X., Lei, H., Ma, X., Lai, T., Song, H., Shi, X., \& Li, J. (2017). Antifungal activity of 1methylcyclopropene (1-MCP) against anthracnose (Colletotrichum gloeosporioides) in postharvest mango fruit and its possible mechanisms of action. International Journal of Food Microbiology, 241: 1-6. 